\title{
KORPORATIVNO UPRAVLJANJE U SRBIJI: PROBLEMI MALIH AKCIONARA
}

\author{
Lazo Kukobat', \\ Sreten Tešanović2, \\ Strahinja Kukić3
}

\author{
1 Visoka brodarska škola \\ akademskih studija, \\ Beograd, Srbija \\ ${ }^{2}$ Visoka škola za primenjene i \\ pravne nauke „Prometej“, \\ Banja Luka, Republika Srpska, BIH \\ ${ }^{3} \mathrm{GO}$ Savski Venac, \\ Beograd, Srbija
}

\begin{abstract}
Apstrakt:
Cilj rada je da ukaže na postojanje problema u oblasti korporativnog upravljanja u Srbiji. Svakako, problem malih akcionara je jedan od dominantnijih. Korporativno upravljanje, kao sistem koji vodi kompanije, je u obavezi da štiti prava svih akcionara pa samim tim i vlasnika manjinskih akcija. Osnovna prava akcionara su, između ostalog, pravo na informisanje o radu kompanije, pravo glasa na skupštini akcionara, pravo na izbor uprave, pravo na profit, pravo na prenos akcija itd. Korporativno upravljanje treba da obezbedi sva navedena i druga prava akcionara. Dakle, uprava pored funkcije vođenja kompanije, kontroliše i nadzire celokupan menadžerski tim, te polaže račun skupštini akcionara. Da bi uprava, odnosno njeni članovi, vodili kompaniju u pravcu ostvarenja postavljenih ciljeva od izuzetnog značaja su relevantne informacije kojima se služe. Tako lakše postižu zadate ciljeve pravdajući poverenje akcionara i same kompanije. Istraživanje korporativnog upravljanja u srpskim kompanijama dovodi do zaključka o postojanju visoke koncentracije vlasništva, te niskog stepena odvojenosti vlasništva i kontrole. Stoga je česta pojava da vlasnici s velikim udelom vlasništva, odnosno veliki akcionari, zadovoljavaju lične interese nauštrb malih akcionara. Posebno su izraženi problemi malih akcionara, tamo gde je stepen njihove zaštite najslabiji.
\end{abstract}

Ključne reči:

akcionari, vlasništvo, kompanija, koncentracija, zaštita.
Korespondencija:

Lazo Kukobat

e-mail:

lazokukobat@gmail.com

\section{UVOD}

Korporacije su najvažnije organizacije modernog društva, koje zadovoljavaju potrebe tržišta, obezbeđuju zaposlenje i stvaraju bogatstvo, te utiču na živote kupaca, zaposlenih, snabdevača, investitora i društva u celini. S obzirom na njihovu važnost, jasno je da im je potreban dobar menadžment. Pre samo dvadesetak godina, izraz „korporativno upravljanje" nije bio opšte poznat ili u svakodnevnoj upotrebi. Danas ovaj izraz upotrebljavaju i oni koji ne razumeju u potpunosti značenje ove sintagme, ali im lepo i pametno zvuči.

Polazeći od pravne interpretacije šireg poslovnog konteksta, korporativno preduzeće predstavlja pravno utemeljeno udruženje koje spaja različite interesne grupe i poslovne subjekte u okviru korporacije, koje putem zajedničkih interesa i ciljeva, dovode do zadovoljavanja svojih ličnih. Ključni momenat za uspešno poslovanje svake kompanije je usaglašavanje mnoštva ciljeva u jedan zajednički.

Korporativno upravljanje treba da obezbedi jednaku odgovornost prema svim akcionarima, kako bi ostvarili maksimalnu korist. U slučaju konflikta ili razmimoilaženja interesa akcionara, dobro korporativno upravljanje sprečava eskalacije i omogućava nastavak poslovanja. 


\section{DEFINISANJE KORPORATIVNOG UPRAVLJANJA}

Korporativno upravljanje se definiše kao sistem koji usmerava i kontroliše kompanije. Upravni odbor je odgovoran za dobro upravljanje kompanijama. U poslednjoj deceniji dogodile su se značajne promene u strukturi upravnih odbora. Postali su manji i profesionalniji, a direktori su bolje informisani i svesni svojih prava i odgovornosti. Početkom XXI veka, svet korporativnog upravljanja se iz osnova promenio. Akcionari biraju direktore i vrše nadzor nad poslovanjem kompanije.

Korporativno upravljanje govori više o ljudskom ponašanju nego o strukturi, pravilima i regulativi poslovanja. Sposobnost direktora najviše utiče na efiksnost odbora. Odnosi unutar odbora podrazumevaju intrige i konspiraciju koliko i poverenje, fer-plej i iskrenost. Društveni položaj članova odbora ili poznato ime u svetu biznisa ne garantuje uspešnost samog odbora, a samim tim i kompanije. Svaki od direktora različito doprinosi (ne)uspešnosti odbora (Cenić, 2007). Mnogi smatraju da se korporativno upravljanje bavi načinima kako da finansijeri kompanija osiguraju svoje investicije i ostvare profit uz pomoć kontrole menažmenta. $\mathrm{Na}$ taj način posmatrano,korporativno upravljanje se svodi na sledeće: akcionari putem skupštine biraju direktora, direktori odlučuju o najvažnijim poslovnim pitanjima i donose odluke većinom glasova. Sam proces donošenja odluka je transparentan, preduzeće usvaja knjigovodstvene standarde, pa su pravila i praksa preduzeća su u skladu sa zakonom. Ovakvo upravljanje kompanijama je karakteristično za razvijene tržišne ekonomije. Međutim, još uvek postoji veliki broj direktora, posebno u zemaljama u tranziciji, koji nemaju adekvatnu obuku i često ne zadovoljavaju očekivanja upravnog odbora. Investitori, bilo da su pojedinačni ili institucionalni, postavljaju sve veće zahteve pred kompanije u pogledu javnosti rada $\mathrm{i}$ istinitosti finansijskih izveštaja.

Područje korporativnog upravljanja obuhvata: korporativni pravni okvir i praksu donošenja odluka u nadzornim odborima i upravama korporacija, razne aspekte korporativnih finansija, zakona koji regulišu poslovanje vrednosnim papirima, stečajne zakone, zakone koji regulišu poslovanje finansijskih institucija, odnose sa zaposlenima, ugovorno pravo i teoriju, vlasnička prava, kompenzacijske zakone i zakone internog informisanja i kontrole (Blair, 1995). Stičući pravni subjektivitet, odnosno postajući „pravna osoba s vlasništvom, potraživanjima i obavezama" (Machlup, 1967), kompanija ujedno prihvata poslovno-finansijsku odgovornost prema svojim osnivačima, vlasnicima, kreditorima, zaposlenima i državi, u pogledu efikasnog upravljanja poverenim sredstvima (Malinović, 2007). Sa pravnog aspekta, za korporativno preduzeće se može reći da predstavlja: „Udruživanje fizičkih osoba u jednu autonomnu pravnu jedinku koja ima vlastitu pravnu ličnost, što joj omogućuje da se bavi poslovima, poseduje imovinu i namiruje dugove." (Guthman \& Dougal, 1970).
U moru internih procedura, svaka komanija ima i „Kodeks korporativnog upravljanja”. Iza ovog naziva se krije jednostavni set procedura koje mogu olakšati rad kompanije i omogućiti bolje definisanje odnosa među pojedinim strukturama. Krajnji cilj kodeksa je da na koncizan i razumljiv način zaposlenima, spoljnim saradnicima i javnosti približi sistem upravljanja kompanije. Njegova uloga nije da zameni važeće zakone, već da osigura usvajanje principa koji će omogućiti poslovnu efikasnost i rast kompanije, ali i povećati poverenje trenutnih i budućih investitora. Takođe, cilj kodeksa je regulisanje odnosa između uprave, nadzornog odbora, akcionara i zaposlenih. Na kodeks treba gledati kao na skup pravila ponašanja čije poštovanje osigurava pravilno poslovanje, privlači investitore i motiviše zaposlene koji ostvaruju bolje rezultate. Kodeks ne treba da bude dugi, suvoparni dokument, koji zbog obilja pravne termilogije malo ko razme, već dokumet koji je napisan jednostavnim i pristupačnim rečnikom. Istina je da kodeksi predstavlju „dobru praksu” usvojenu iz drugih zemalja, ali treba krenuti od pretpostavke da epitet dobre prakse ne bi dobili da nisu unapredili poslovanje kompanija koje su ih usvojile, a to je krajnji cilj svakog poslovnog subjekta.

SEE Business Solutions kodeks upravljanja privrednim društvima definiše kao pravno neobavezujući skup principa, standarda i preporučenih delovanja pozitivnih iskustava, kojeg prihvata određeno telo kompanije s ciljem određivanja delotvornijeg upravljanja samom kompanijom. Pojedne države Evropske unije do sadu su prihvatile više od četrdeset takvih kodeksa, a neki su bili prihvaćeni i na naddržavnoj ravni (npr. Organizacija za ekonomsku saradnju i razvoj OECD Principi korporativnog upravljanja). Brojni kodeksi upravljanja prihvaćeni su od 1997. godine. Najviše iskustva ima Velika Britanija, sa više od deset kodeksa. OECD Principi korporativnog upravljanja odobreni su od strane OECD ministara 1999. godine. Principima je unapređen program korporativnog upravljanja i obezbeđene su posebne smernice za zakonske i regulatorne inicijative. Usvojeni principi obezbeđuju dobre poslovne običaje, neobavezujuće standarde, i mogu se prilagoditi različitim zemaljama i regijama. Takođe, važno je istaći razmenu iskustava između zemalja članica, pa čak i među zemljama koje nisu članice.

Principi predstavljaju transparentnost izveštavanja, odgovornost top menadžera i glavnih aktera, efikasnu proveru i ravnotežu. „Menadžeri u javnom i privatnom sektoru, akcionari i zaposleni treba da budu svesni da najbolja praksa korporativnog upravljanja može voditi ekonomski rast i povećati poverenje lokalnih i međunarodnih investitora u domaću privredu" (Zatoni, 2006). To je za dobrobit celog sistema. Isti autor naglašava da korporativno upravljanje u užem smislu, podrazumeva kompoziciju, strukturu i procese na osnovu kojih bord direktora kompanije treba da obezbedi odgovornost prema akcionarima i njihovu maksimalnu korist. U širem smilu, odnosi se na celi set zakonskih, kulturnih i institucionalnih aranžmana koji unapređuju upravljanje kompanijom. 
Na kraju, ali ne i najmanje važno, posebno se preporučuje usvajanje i primena kodeksa korporativnog upravljanja na osnovu najbolje svetske prakse.

\section{KORPORATIVNO UPRAVLJANJE U SRBIJI}

U zemljama u tranziciji, uglavnom, je izvršena privatizacija preduzeća i formirana su akcionarska društva. Mnogi članovi akcionarskih društava nisu informisani o svojim pravima i obavezama, nisu svesni svoje uloge menadžera, članova uprave ili akcionara. Mnoga akcionarska društva nisu u mogućnosti da investitorima daju pravovremenu i korisnu informaciju, što predstavlja rizik. Samo potpuna, istinita informacija, vodi transparentnosti koja investitorima i akcionarima omogućuje kontinuriranu procenu akcionarskih društva i prilagođavanje procene akcijama akcionarskih društava. Kontinuirano - fino podešavanje podstiče potpuniju procenu tržišta i stabilnije cene akcija. Uvođenje korporativnog upravljanja u srpske kompanije, u odnosu na druge zemlje u tranziciji, je složeno i komplikovano. Period ratnih dešavanja tokom raspada bivše Jugoslavije, ekonomskih sankcija, dugogodišnje političke nestabilnosti i razni modeli privatizacije, doveli su do toga da su naša preduzeća potpuno nespremna ušla u proces restrukturiranja i tržišnog načina poslovanja. Mnoge kompanije su nestale sa tržišne scene, likvidacijom ili kroz dugotrajne, zastarele, stečajne postupke. Posebno ograničenje u razvoju kompanija na području upravljanja predstavlja nestručnost menadžerskog kadra. Nedostatak adekvatnog menadžerkog kadra u svim sektorima privrede i društva u Srbiji, predstavlja nastavak prakse iz prethodnog perioda (Radosavljević, 2008).

U vremenu kada se rezultati poslovanja preduzeća ne vezuju za berzansku vrednost, ne postoji ni veliki interes da se kroz uređeno korporativno upravljanje postigne bolja vrednost, a samim tim i veća zainteresovanost investitora. Investitori bi više sredstava uložili u akcije kompanije kojom se upravlja tržišno i odgovorno, nego u akcije kompanije koja ima slične finansijske pokazatelje, a kojom se neodgovorno upravlja. Današnji investitori ogromnu pažnju posvećuju upravljanju kompanijama, odnosno kvalitetu menadžmenta, jer su za obavljanje poslova upravljanja potrebna veća znanja i umeća u odnosu na druge funkcije i poslove. Skladnim delovanjem menadžera, odnosno integracijom u jedinstven sistem, omogućava se povećanje uspešnosti razvoja kompanije (Radosavljević, 2008). U suprotnom, postojanje nekompetentnih organa uprave i članova nadzornih odbora, predstavalja veliki problem za kompaniju. Često se za članove uprave biraju lojalni i poslušni ljudi bez stručnih sposobnosti, neretko pozicijom u upravi bivaju nagrađeni i partijski funkcioneri, što vodi ka urušavanju sistema dobrog korporativnog upravljanja.

Praksa korporativnog upravljanja se značajno razlikuje od zemlje do zemlje, pa čak i od kompanije do kompanije u istoj zemlji. Iskustvo pokazuje da je glavni razlog za ovakvu situaciju, bar u zemljama u tranziciji, to što se pravila za dobro i efikasno korporativno upravljanje u praksi ne primenjuju. Nedavna istraživanja (Daron et al., 2001) potvrđuju ovu tezu, ukazujući da je primena pravila i vladavina prava centralna funkcionalna razlika između razvijenih tržišnih ekonomija, s jedne strane, i ekonomija u razvoju, s druge strane. Otuda hipoteza da rešenja trebe tražiti u institucijama koje se manje oslanjaju na prinudnu primenu prava od strane države. Koncentracija vlasništva se u mnogim tranzicionim zemljama pokazala kao najefikasniji mehanizam korporativnog upravljanja. Dok najveći izazov reformatorima predstavlja izbor najboljeg načina da se reguliše delovanje velikih aktivnih akcionara i da se pri tom uravnoteže i kontrolišu menadžerska diskrecija, zaštita manjinskih akcionara i negativni uticaji koncentracije na tržište kapitala. Srbija je zemlja u tranziciji, pa je institucionalni aspekt analize od vitalnog značaja. Tako definisana analiza, u sferi korporativnog upravljanja, je neophodna jer su institucije nerazvijene i ta činjenica odlučujuće utiče na kvalitet zaštite koju uživa akcionar, rizik koji on nosi, podsticaje i oportunitetne troškove, a samim tim i cenu kapitala.

Iako trenutna zakonska pravila i rešenja omogućavaju akcionarima u Srbiji dobar pravni okvir za kontrolu upravljanja kompanije, u praksi postoji mnoštvo problema i nesuglasica između akcionara, koje naročito idu na štetu vlasnika malih akcija. Jedan od glavnih razloga za većinu problema viđen je u postojećoj vlasničkoj strukturi, lošem funkcionisanju tržišta kapitala, loše uređenim odnosima akcionara i menadžmenta, nekompetentnosti upravnih i nadzornih odbora, te nedovoljnoj edukaciji u oblasti korporativnog upravljanja.

Konstrukcija indeksa korporativnog upravljanja za Srbiju ukazuje da postoji nedvosmislen raskorak između zakonodavnih normi i njihove primene, odnosno prava i faktičkog stanja. Osnovni problem niskog nivoa kvaliteta korporativnog upravljanja nije u pravnim normama već, nažalost, u slabosti institucija (Ječmenica \& Veljović, 2007). Glavni problemi se odnose na neprimenjivanje postojećih zakonodavnih odredaba, neiskustvo, nerazjašnjene nadležnosti institucija, i prihvatanje zakonodavnih rešenja ne vodeći računa o njihovoj usklađenosti sa korporativnim prilikama u Srbiji i regionu. Zbog svega navedenog, formirani indeks daje de jure sliku kvaliteta korporativnog upravljanja, ali ne i njenu de facto sliku. Korporativno upravljanje u Srbiji se ne može proceniti sa naučnom sigurnošću, bez procene efikasnosti primene postavljenih zakonodavnih normi.

\section{MALI AKCIONARI: PROBLEMI I MOGUĆNOST ZAŠTITE}

Prema istraživanju, u srpskim kompanijama postoji visok nivo koncentracije vlasništva. Gotovo po pravilu, vlasništvo i kontrola su usko povezani, što nije u skladu sa principima dobrog korporativnog upravljanja. Otuda se velikim akcionarima pruža mnoštvo mogućnosti za zloupotrebu. Oni se 
neretko ponašaju kao da su jedini vlasnici, te pravo glasa i odlučivanja malih akcionara biva potpuno marginalizovano (npr. Interkomerc, Foodland, Tropik, Kotex, Toza Marković, $P K B)$. Budući da korporativno upravljanje predstavlja vrlo važan element u funkciji konkurentnosti velikih srpskih preduzeća, traženje institucionalnih rešenja, koja bi zaštitila interese malih akcionara, $\mathrm{u}$ odnosu na dominantne vlasnike, predstavlja regulatorni i istraživački problem par excellence. Pitanje korporativne kontrole proizilazi iz stanja u odnosima relevantnih elemenata za upravljanje kompanijama, kojeg određuju mehanizmi kontrole, postojeći pravni okvir i nivo koncentracije vlasništva. Sistemi korporativnog upravljanja se razlikuju od zemlje do zemlje. Uočavamo da je veliki problem korporativnog upravljanja, na koji upozoravaju istraživači anglosaksonskog poslovnog kruga, problem oportunog ponašanja menadžmenta i slabih, disperzivnih vlasnika. Veliki broj malih akcionara dovodi do povećanja i odvojenosti vlasništva i kontrole, što je osnovna karakteristika modernih poslovnih sistema (Berle \& Means, 1932).

Visoka disperzija vlasništva neminovno dovodi i do nezainteresovanosti investitora. Natočito je karakteristična za američke kompanije, ali ne i za ostale zemlje sveta (La Porta et al., 1999). U zemljama EU dominantan je model korporativne kontrole od strane velikih akcionara. Procenjuje se da je koncentracija vlasništva merena kroz udeo najvećeg vlasnika na nivou većine zemalja u tranziciji - između 40\% i $50 \%$. Takođe, veliki akcionari imaju svoje probleme koji, iako nisu vezani za kontrolu menadžmenta i sigurnost interesa vlasnika, predstavljaju kamen spoticanja razvoja kompanije. Ti problemi predstavljaju čest konflikt između velikih akcionara, a poznato je da su njihovi predstavnici članovi raznih interesnih grupa i nadzornih odbora, te njihov glas određuje pravac i cilj razvoja kompanije.

Izuzetno visoka koncentracija vlasništva utiče na probleme korporativnog upravljanja u Srbiji, tako da mali broj vlasnika kontroliše naše kompanije (Delta agrar, Squadra, Fili pili, Coolfood, Frikom, Imlek, Carnex, Interkomerc). Samim tim, vlasništvo i kontrola su usko povezani, što znači da mali akcionari gotovo i ne učestvuju u upravljanju kompanijama. Njihov glas nije presudan i odluke se donose preglasavanjem, često bez konsultacija sa svim akcionarima. Istraživanje koje je sprovedeno "face-to-face" anketiranjem članova uprave, direktora i drugih visokopozicioniranih zaposlenih u 30 kompanija, akcionarskih društava, potvrđeno je da postoji veliki uticaj vlasnika kroz nadzorne odbore, odnosno članove u tim odborima, na sistem korporativnog upravljanja i na strateške ciljeve kompanije, što sve jasno govori o načinu korporativne kontrole u sistemima visoke koncentracije vlasništva.

Srpsko zakonodavstvo je reformisano i usmereno ka pravcu tržišnog poslovanja. Mnogi doneti zakoni su moderni i savremeni. Ipak, postoje i zakoni koji su prepuni manjkavosti, naročito oni koji regulišu oblast finansija. Dosta vremena se izgubilo u prethodnom periodu, usled pokušaja da se u brzini nadoknadi propušteno, što rezultira i određenom količinom manjkavosti. Navedeni problem se rešava izmenama i dopunama zakona, a neretko i novim zakonskim normama. Međutim, primena zakona u praksi, odnosno njegova implementacija, predstavlja najveći problem srpskog zakonodavstva. Mnoge oblasti su zakonski dobro regulisane, ali zakoni nisu sprovedeni u praksi, što dovodi do nerazumevanja, pa čak i do konflikta.

Za srpske kompanije veliki problem predstavlja zloupotreba položaja većinskih akcionara, čija kontrola može postati podređena isključivo ličnom cilju. To je ujedno i povod za najčešći konflikt u kompanijama, konflikt između velikog akcionara ili manjeg broja većinskih akcionara, i velikog broja malih, razvlašćenih, akcionara. Naravno, menadžment je u službi velikog/ih akcionara, čime se dodatno otežava položaj malih akcionara. Centar za liberalno-demokratske studije navodi da se zloupotrebom kontrole velikih akcionara, na račun malih akcionara, najčešće dolazi do:

(1) ogromne zarade menadžera, gde oni vođeni ličnim interesima slepo slede instrukcije i interese većinskog vlasnika;

(2) povezivanja poslova kompanije sa licima u drugim kompanijama, a koji su štetni za poslovanje, često i sa drugim kompanijama istih vlasnika;

(3) zloupotreba informacija za lični interes, odnosno skrivanje istih od ostalih-malih akcionara, čime se dovode u neravnopravan položaj prilikom odlučivanja i glasanja; i

(4) delistiranje manjinskih akcija, najčešće integracijom preduzeća.

Navedene pojave zloupotrebe od strane većinskih akcionara su u velikoj meri prisutne u srpskim kompanijama koje su bile predmet istraživanja, ali čini se da je najdominantnija pojava poslovnog povezivanja kompanija koje kontrolišu isti vlasnici ili njihovi prijatelji, bez obzira što takva saradnja najčešće nanosi štetu kompaniji. Gotovo da ne postoji domaći poslodavac, koji ne poseduje veći broj kompanija i preduzeća koja su po pravilu u poslovnom odnosu. Takvu praksu trebalo bi iskoreniti a poslovne odnose graditi, isključivo, na bazi interesa kompanije i akcionara. Takođe, treba naglasiti da su informacije netransparentne za male akcionare, što dovodi do toga da pojedine ugovore kompanije godinama ne dobijaju na uvid. Ovakve i slične stvari ne bi smele da se dešavaju u sistemu dobrog korporativnog upravljanja.

Najpoznatije metode zaštite malih akcionara, prema istraživanju Centara za liberalno-demokratske studije su:

(1) jačanje položaja malih akcionara pravilom ,jedna akcija jedan glas" čime se sprečava tkz. privilegovano glasanje koje bi imali pojedini vlasnici, a samim tim bi postojala i mogućnosti zloupotrebe,

(2) redovno i relevantno informisanje akcionara o stanju u kompaniji, 
(3) razvijen sistem nezavisnog verifikovanja knjiga akcionarskih društava,

(4) jačanje efikasnosti upravnog odbora,

(5) precizna regulacija konflikta interesa,

(6) prava podnošenja tužbi protiv većinskog vlasnika za zloupotrebu, kao i

(7) borba za skupštinske glasove, uz pretpostavku da kontrolni vlasnik nije i većinski.

$\mathrm{Na}$ osnovu podataka dostupnih na sajtu Centara za liberalno-demokratske studije, osnovni problemi metode zaštite malih akcionara su sledeći: ako je zaštita malih akcionara veća to više ugrožava upravljačka prava velikih akcionara. Često se ugrožava i jednakost prava akcionara, odnosno demokratsko načelo „jedna akcija jedan glas”. Zato se velika pažnja posvećuje uspostavljanju balansa između odluka velikih akcionara, kroz menadžerski tim, i zaštite interesa malih akcionara. $\mathrm{Na}$ ravno, zlouptreba je moguća i česta je pojava u praksi, kojom se od strane velikih akcionara i menadžera ugrožavaju prava malih. Da bi male akcionare koliko-toliko zaštitili pribegava se metodama zaštite, ali one, na neki način, ograničavaju velike akcionare.

Zaštita akcionara, korporativno upravljanje i tržište akcija spadaju u kategoriju institucija. Zaštita akcionara je zaštita vlasnika akcija, a svojina je institucionalna osnova tržišta. Stoga opredeljenje za tržišnu privredu ima ključne implikacije u pogledu vlasništva, jer su ta dva fenomena međusobno uslovljena. Drugim rečima, veza između privatne svojine tržište ekonomije - demokratije, tj. državne (društvene) svojine - komandne ekonomije - partijske države nije slučajna već zakonita. Fondacija za razvoj ekonomske nauke navodi da zakoni i kvalitet njihove primene imaju presudan značaj u zaštiti prava malih akciona, naročito u zemljama u tranziciji, jer kada sopstveni pravni sistem ne štiti eksterne i manjinske akcionare, ne funkcioniše ni korporativno upravljanje i eksterno finansiranje. Pošto proces privatizacije još uvek nije završen, značaj zaštite prava malih akcionara ima posebnu ulogu u Srbiji. Mnoga javna preduzeća će se uskoro otvoriti, čime će se veliki broj građana Srbije naći u ulozi malog akcionara (Đulić \& Kuzman, 2012). Dobro korpotativno upravljanje može se razvijati i usavršavati samo uz doslednu primenu donetih zakona.

\section{ZAKLJUČAK}

Ambijent i uslovi za vođenje kompanija u Srbiji su zadovoljavajući. Većina zakona se usklađuje sa zakonodavstvom zemalja Evropske unije. Preostali zakoni, neophodni za dalji ekonomski razvoj zemlje, su u pripremi i očekuje se njihovo skoro usvajanje i primena. Investitori i vlasnici kompanija, uz pomoć korporativnog upravljanja, kontrolišu i usmeravaju kompanije prema svojim poslovnim ciljevima. Nizak nivo kvaliteta korporativnog upravljanja prvenstveno proizilazi iz slabosti institucija (Ječmenica \& Veljović, 2007). Naime, pravni okviri postoje ali njihova dosledna primena u praksi izostaje. Kompanije u Srbiji karakteriše visoka koncentracija vlasništva, gde veliki akcionari ili mali broj većinskih akcionara imaju svu upravljačku moć, a veliki broj malih akcionara je na margini odlučivanja. Takođe, postoji nizak stepen odvojenosti vlasništva i kontrole u kompanijama što otvara mogućnosti da većinski akcionari ostvare svoje interese, ali na račun malih akcionara. Prava malih akcionara su često ugrožena, a posebno ako su sistemi njihove zaštite slabi. Radi zaštite prava malih akcionara posebno je važno očuvanje pravila ,jedna akcija jedan glas” i slobodan pristup informacijama od značaja za poslovanje kompanije. Kodeksi upravljanja, moderni zakoni i njihova obavezujuća primena uticaće na bolju zaštitu prava malih akcionara.

\section{LITERATURA}

Berle, A., \& Means, G. (1932). The Modern Corporation and Private Property. New York: Macmillan.

Blair, M.M. (1995). Ownership and control: Rethinking corporate governance for the twenty-first century. Washington, DC: Brookings Institution.

Cenić, S. (2007). Sudbina upravljanja u uslovima poltronizacije. Preuzeto 12.09.2016. sa http://www.nezavisne.com/kolumne/vijesti/4381/Sudbina-upravljanja-u-uslovima-poltronizacije.html

Centar za liberalno-demokratske studije. (2008). Korporativno upravljanje: pet godina kasnije. Preuzeto 14.09.2016. sa http://www. clds.rs

Daron, A., Johnson, S., \& Robinson, J.A. (2001). The Colonial Origins of Comparative Development: An Empirical Investigation. American Economic Review, 91(5), 1369-1401.

Đorđević, M. (2005). Korporativno upravljanje-vlasništvo, kontrola i prava akcionara. Beograd: Privredna izgradnja.

Đulić, K., \& Kuzman, T. (2012). Zaštita prava manjinskih akcionara: pravni okvir i primena. Kvartalni monitoring, br. 30, jul-septembar 2012, 86-95.

Fondacija za razvoj ekonomske nauke. (2015). Publikacije. Preuzeto 14.09.2016. sa http://www. fren.org.rs

Guthmann, H.G., \& Dougall, H.E. (1970). Corporate financial policy. New Delhi: Prentice-Hall. Ivanović, M. (2004). Agropreduzetništvo u procesima tranzicije. Novi Sad: Savremena poljoprivredna tehnika

La Porta, R., Lopez-de-Silanes, F., \& Shleifer, A. (1999). Corporate Ownership Around the World. Journal of Finance, 54(2), 471-517. doi:10.1111/0022-1082.00115

Machlup, F. (1967). Theories of the firm: marginalist, behavioral, managerial. The American Economic Rewiev, 57(1), 1-33.

Malinović, D. (2007). Specifičnosti korporativnog preduzeća. Beograd: Ekonomski fakultet.

OECD. (2004). OECD principi korporativnog upravljanja. Preuzeto 14.09.2016. sa http://www.ecgi.org/codes/documents/ principles_se_final.pdf 
Pisror, K., Raiser, M., \& Gelfer, S. (2000). Law and Finance in Transition Economies. The Economics of Transition, 8(2), 325-368. doi:10.1111/1468-0351.00047

Radosavljević, Ž. (2008). Menadžment znanja i(li) znanje u menadžmentu. Beograd: Centar za edukaciju rukovodećih kadrova i konsalting.

SEE Business Solutions. (2015). Publikacije. Preuzeto 14.09.2016. sa http://www. korporativno-upravljanje.ba
Veljović, K., \& Ječmenica, T. (2007). Kvalitet finansijske regulative. Kvartalni monitoring ekonomskih trendova i politika u Srbiji, 9 (april-jun). Preuzeto 14.09.2016. sa http://fren.org. rs/sites/default/files/qm/km9-00-ceo.pdf

Zattoni, A. (2006). Assetti proprietari e corporate governance. Milano: Egea.

\section{CORPORATE GOVERNANCE IN SERBIA: PROBLEMS OF SMALL SHAREHOLDERS}

\section{Abstract:}

The paper aims to show the existence of problems in corporate governance of companies in Serbia. One of the dominant problems is the problem of small shareholders. Corporate governance as a system that manages companies is obliged to protect the rights of all shareholders including the owners of minority shares. Basic shareholder rights include, among other things, the right to be informed about the work of the company, to vote at shareholders meetings and choose the management, gain profit, transfer shares, etc. All the above mentioned and other shareholders' rights are to ensure corporate governance. So, the management, along with the function of managing the company, controls and supervises the entire management team and reports at the shareholders' meeting. In order to lead the company towards achieving the set goals, it is of great importance for the members of the management to get relevant information. Thus, they achieve the set goals more easily, justifying the trust of shareholders and the company itself. The study of corporate governance in Serbian companies points to the conclusion about the existence of high concentration of the ownership and low degree of separation of ownership and control, because of which the large shareholders satisfy personal interests at the expense of small shareholders. In companies where the protection of small shareholders is the weakest, they have the most prominent problems.

\section{Keywords:}

shareholders, ownership, company, concentration, protection. 